\title{
New Paradigm for Management of Hepatocellular Carcinoma by Imaging
}

\author{
Ijin Joo Byung Ihn Choi \\ Department of Radiology, Seoul National University Hospital, Seoul, Korea
}

\author{
Key Words \\ CT · Hepatocarcinogenesis · Hepatocellular carcinoma - MRI · Ultrasonography
}

\begin{abstract}
Based on recent clinical practice guidelines, imaging is largely replacing pathology as the preferred diagnostic method for determination of hepatocellular carcinoma (HCC). A variety of imaging modalities, including ultrasound (US), computed tomography (CT), magnetic resonance imaging (MRI), nuclear medicine, and angiography, are currently used to examine patients with chronic liver disease and suspected HCC. Advancements in imaging techniques such as perfusion imaging, diffusion imaging, and elastography along with the development of new contrast media will further improve the ability to detect and characterize HCC.

Early diagnosis of HCC is essential for prompt treatment, which may in turn improve prognosis. Considering the process of hepatocarcinogenesis, it is important to evaluate sequential changes via imaging which would help to differentiate HCC from premalignant or benign lesions. Recent innovations including multiphasic examinations, high-resolution imaging, and the increased functional capabilities available with contrast-enhanced US, multidetector row $\mathrm{CT}$, and MRI have raised the standards for HCC diagnosis. Although hemodynamic features of nodules in the cirrhotic liver remain the main diagnostic criterion, newly developed cellspecific contrast agents have shown great possibilities for improved HCC diagnosis and may overcome the diagnostic dilemma associated with small or borderline hepatocellular lesions. In the 20th century paradigm of medical imaging, radiological diagnosis was based on morphological characteristics, but in the 21st century, a paradigm shift to include biomedical, physiological, functional, and genetic imaging is needed. A multidisciplinary team approach is necessary to foster an integrated approach to HCC imaging. By developing and combining new imaging modalities, all phases of HCC patient care, including screening, diagnosis, treatment, and therapy, can be dramatically improved.

Copyright (C) 2012 S. Karger AG, Basel
\end{abstract}

Byung Ihn Choi, MD

Department of Radiology, Seoul National University Hospital

101 Daehakro, Jongno-gu, Seoul 110-744 (Korea)

Tel. +82 22072 2515, E-Mail bichoi@snu.ac.kr 


\section{Introduction}

Hepatocellular carcinoma (HCC) is the 6th most common malignancy worldwide, representing $6 \%$ of all cancers. It is highly prevalent in Asia and Sub-Saharan Africa and is currently increasing in Western countries [1-7]. Majority of HCCs develop in patients with risk factors such as chronic hepatitis B or C and non-viral liver cirrhosis, which may be associated with alcoholic liver disease or non-alcoholic fatty liver disease $[5,8,9]$. Unfortunately, HCC is a devastating cancer with a five-year survival rate of $<5 \%$ when diagnosed at an advanced stage [10]. Because early diagnosis of HCC followed by prompt treatment can increase patient survival, HCC surveillance is important, particularly in high-risk populations [10-12].

Imaging studies play a key role in HCC diagnosis. According to recent clinical practice guidelines for HCC, use of imaging techniques is increasing and the importance of biopsy is decreasing [13-17]. Classically, HCC diagnosis with imaging techniques is based on enhancing patterns according to the time sequence or phase, experienced as high attenuation or signal intensity in the arterial phase and a washout pattern in the portal venous and equilibrium phases.

Imaging tools for HCC include ultrasound (US), computed tomography (CT), magnetic resonance imaging (MRI), angiography, and fusion imaging. These techniques have continuously evolved during recent decades, driving a paradigm shift in HCC imaging. Herein we present a review of imaging techniques for HCC with a focus on recent progress, diagnosis of hepatocarcinogenesis using these methods, current guidelines, and future perspectives.

\section{Recent Imaging Techniques}

\section{Ultrasound}

Contrast-enhanced US

Contrast-enhanced US (CEUS) is useful for the characterization of focal liver lesions. Using microbubble contrast agents, it is possible to obtain hemodynamic information from hepatic nodules with multiphasic US images on a real-time basis, making it feasible to characterize HCC and to differentiate it from other hepatocellular nodules related to cirrhosis [18-22]. Second-generation contrast agents, such as SonoVue ${ }^{\circledR}$ or Definity ${ }^{\circledR}$, are useful for the assessment of tumor vascularity because these agents can be used in continuous bubble imaging at a low mechanical index. With CEUS, typical findings related to HCC are hypervascularity of the lesion relative to the liver parenchyma in the arterial phase and washout in the portal venous or equilibrium phase, which are similar to those obtained with CT and MRI $[20,22-24]$.

A new contrast agent, Sonazoid ${ }^{\mathrm{T}}$, has recently been introduced in Japan. Because Sonazoid is taken up by Kupffer cells, it allows for the evaluation of hepatic nodules in the vascular phase as well as the Kupffer (post-vascular) phase. HCC shows hypervascularity in the vascular phase and defects in the Kupffer phase with Sonazoid CEUS; therefore, this agent is useful in the diagnosis and estimation of the histological grade of HCC [25-28]. Recently, Kudo et al. reported innovative defect reperfusion US imaging as a very useful method for the detection and characterization of HCC [29].

\section{US Elastography}

US elastography is a technique for studying the stiffness of tissue. While the concept is similar to that of manual palpation, elastography, a virtual palpation technique, can provide more quantitative and objective information than manual palpation. 
Recently, shear wave elasticity imaging (SWEI) was introduced for use with deep organs including the liver [30]. There are currently three SWEI techniques: transient elastography (Fibroscan ${ }^{\circledR}$ ), acoustic radiation force impulse imaging, and supersonic shear imaging. Because the degree of liver fibrosis is a predictive factor for HCC development [31, 32], identification of the presence and severity of liver fibrosis is important. Many studies have reported the efficacy and usefulness of US elastography for the evaluation of liver fibrosis by measuring the stiffness of the liver [33-42]. Therefore, US elastography is a promising non-invasive surrogate marker for evaluating liver fibrosis and can be used as an alternative to liver biopsy.

Volumetric US

Volumetric US has progressed because of the development of the transducer, which performs volume acquisition via freehand acquisition through mechanical or electronic scanning $[43,44]$. Nowadays, the number of transducer elements currently used is greater than 9,000.

Volumetric US provides three-dimensional (3D) anatomic information, which is useful in clinical practice. It can measure the size of organs and lesions more precisely than conventional two-dimensional US, which helps in diagnosis and monitoring of treatment response [45-48]. This technique also facilitates needle localization for local-regional HCC treatment and biopsies of indeterminate hepatic nodules [49].

$3 \mathrm{D}$ visualization of tumor vessels including feeding arteries is possible with the 3D power Doppler US imaging technique; thus this technique is helpful in HCC diagnosis and is a possible alternative to angiography [50-52]. In addition, 3D CEUS may be a useful method for the evaluation of therapeutic efficacy of local-regional HCC treatment [53-55].

\section{CT}

Dual energy CT

The clinical incentive to use dual energy CT (DECT) is that DECT can measure chemical composition by the dual energy index. This index characterizes the spectral behavior of material. The potential clinical applications of this technology include virtual non-contrast imaging, determination of biliary stone composition, estimation of average iron or fat content in the liver, and perfusion of the liver [56,57]. Given that iodinated contrast material provides greater X-ray attenuation at low tube voltage settings, low $\mathrm{kVp}$ images of dual energy datasets might be more sensitive for the detection of hypervascular lesions such as HCC than high kVp images, but may result in an increase in high image noise [58-61]. Using blending techniques of dual energy datasets, images with the contrast of the low kVp images and the noise characteristics of the high $\mathrm{kVp}$ images can be created [62-64].

\section{Perfusion CT}

Perfusion CT is an in vivo functional imaging. It provides quantitative data regarding perfusion parameters and differentiates diverse tumor tissues based on perfusion behavior [65]. Because perfusion parameters reflect tumor vascularity, this is regarded as a useful tool for monitoring the response to anti-angiogenic drug treatment [66-69] and local-regional treatment in HCC patients [70-73]. However, a major problem with perfusion CT is high radiation exposure, making it difficult to use this technique for HCC surveillance or serial examinations for the evaluation of treatment response $[74,75]$.

\section{MRI}

Diffusion-weighted MRI

MR diffusion-weighted imaging (DWI) is a technique that obtains image contrasts based on differences in the motion of water molecules between tissues [76]. Because recent advances in MRI have overcome motion-related problems, DWI is widely used for abdominal imag- 
ing. DWI does not require contrast agents and has a short acquisition time $[77,78]$. Therefore, many recent studies have examined its clinical applications, especially for oncologic imaging. In terms of HCC, DWI can improve lesion detection [79-81], predict the histological grade of HCC [82-85], and assess treatment response and recurrence [86-90].

\section{MR elastography}

MR elastography (MRE) is an emerging technique that allows for the quantitative assessment of the mechanical properties of tissues. In the field of HCC surveillance, as mentioned previously, detection and quantification of liver fibrosis is quite important. Based on the results of recent studies, MRE is a non-invasive, reproducible, and accurate method for the quantitative assessment of liver fibrosis. It can be used to differentiate normal liver from fibrotic liver and evaluate the stage of fibrosis [91-98]. Venkatesh et al. reported that MRE would be a promising tool for assessing solid liver tumors by differentiating them from benign and malignant liver tumors [99]. Further investigations are needed to clarify the value of MRE for focal liver lesions.

MRI using new contrast media

Recently, hepatocyte-specific contrast agents such as gadoxetic acid (Primovist; Bayer Healthcare, Berlin, Germany) and gadobenate dimeglumine (MultiHance; Bracco, Milan, Italy) have become commercially available. These agents are taken up by normally functioning hepatocytes and are excreted into the biliary system. Because hepatocyte-specific contrast agents have a biphasic nature, the perfusion function in the vascular phase and the hepatocyte function in the hepatobiliary phase can be evaluated [100-102]. Dynamic MRI using extracellular contrast agents provides sufficient information to make a confident diagnosis of typical enhancing HCC. However, there are hypovascular HCCs and hypervascular HCCs without washout. Thus, in addition to the enhancement pattern, more information is needed to diagnose indeterminate nodules. Hepatocyte-specific contrast agents (so-called dual functional agents) may provide additional functional information that can improve the detection and characterization of HCCs [103-110].

\section{Hybrid Imaging}

Hybrid imaging such as positron emission tomography (PET)-CT, single photon emission computed tomography (SPECT)-CT, MR-PET, MR-optical imaging (OI), and virtual US can be used for HCC diagnosis and treatment monitoring.

Hybrid imaging with MR-PET is an emerging technique providing high soft tissue contrast as well as functional information for the evaluation of tissue microenvironment and cellular and molecular processes. There have been several reports concerning the usefulness of MR-PET for liver tumors [111,112].

Virtual US, a fusion imaging technique that combines US with other imaging modalities such as CT or MRI, may be helpful in HCC diagnosis $[113,114]$ and can be applied for local treatment or biopsy of hepatic lesions, particularly those lesions that are poorly visualized with US alone [115, 116] (fig. 1).

\section{Imaging Diagnosis of Hepatocarcinogenesis}

The role of imaging for HCC surveillance is early detection and characterization; therefore, an adequate understanding of hepatocarcinogenesis is necessary. There are two pathways involved: one is the de novo pathway and the other is a multistep pathway. The de novo pathway involves the development of HCC without a background of chronic liver disease or 

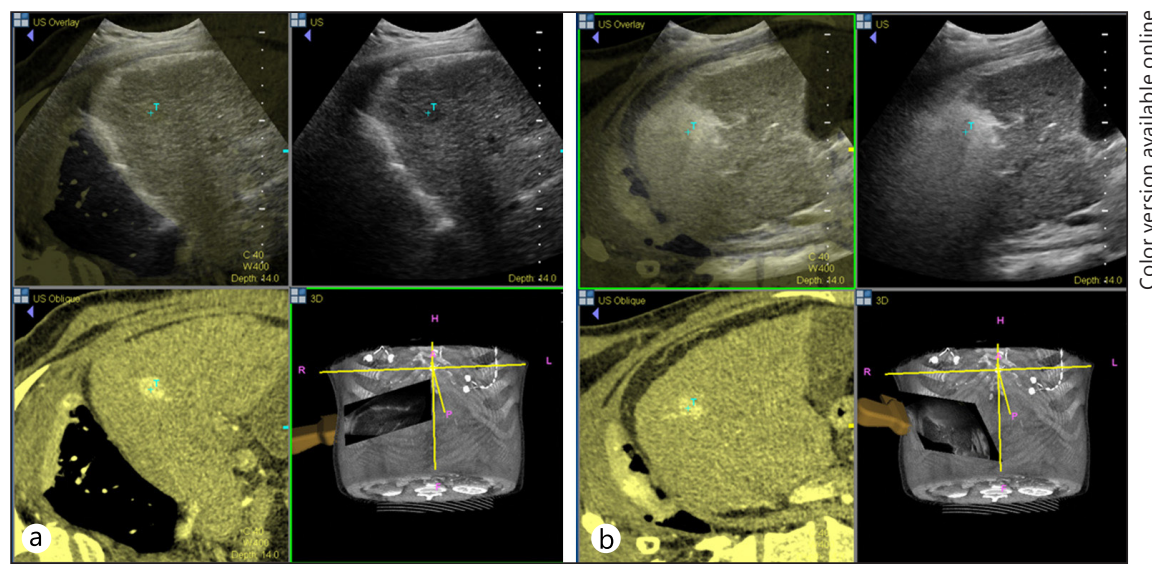

Fig. 1. Real-time virtual US with a simultaneous display of US and contrast-enhanced CT images. A 1.5cm HCC located in segment seven of the liver in a patient with liver cirrhosis. a Using a hybrid imaging technique, the CT-detected hypervascular nodule can be found on US. b After radiofrequency ablation of the tumor, the safety margin can be assessed by registering pre-procedural images with post-procedural images.

liver cirrhosis. The multistep pathway involves the development of HCC with a background of liver cirrhosis from regenerating nodules (RN) going through low-grade (LG) dysplastic nodules (DN), high-grade (HG) DN, early HCC, and finally advanced HCC $[117,118]$. In terms of histopathological changes during hepatocarcinogenesis, hemodynamic and molecular profiles are altered progressively [119-122]. Imaging tools for evaluating hepatocarcinogenesis include contrast-enhanced US, CT, MR, angio-CT for assessing hemodynamic changes and liver-specific imaging using a reticuloendothelial system (RES) agent or a hepatocyte-specific contrast agent for assessing cellular and functional changes.

\section{Hemodynamic Changes}

When a nodule becomes DN during hepatocarcinogenesis, normal hepatic arterial flow is decreased while portal venous flow is maintained. In cases of early HCC, abnormal hepatic arterial flow increases and portal venous flow decreases. Finally, in cases of advanced HCC, the tumor is supplied only by the abnormal hepatic artery and is usually seen as a hypervascular lesion on imaging studies $[119,123]$. Such intranodular hemodynamic changes can be well visualized with CT hepatic angiography and CT arterial portography [118, 121, 124, 125].

\section{Kupffer Cells}

We can evaluate Kupffer cells in the liver by immunohistochemical staining with the anti-human macrophage antibody anti-CD68. According to previous studies, a decrease in the number of Kupffer cells may play an important role in hepatocarcinogenesis $[126,127]$. Superparamagnetic iron oxide (SPIO) particles are a MR contrast media that are sequestered by phagocytic Kupffer cells in the normal RES. Because the degree of enhancement of SPIO-MR is correlated with the number of Kupffer cells, SPIO-MRI might be helpful in differentiating HCC from DN and predicting the histological grade of HCC [128-132].

\section{Bile Duct}

In hepatocarcinogenesis, normal bile canaliculi progressively decrease and are replaced by tumor cells. Carcinoembryonic antigen (CEA) immunostaining is useful for the demonstration of bile canaliculi in pathological specimens. The presence of many bile canaliculi in RN 
Fig. 2. Transverse MR images obtained in the arterial (a) and portal-venous (b) phases show an arterial enhancing nodule without washout. This nodule shows high signal intensity in the hepatobiliary phase (c), which is an uncommon finding of HCC. (d) Angio-CT and transarterial chemoembolization confirm HCC diagnosis.
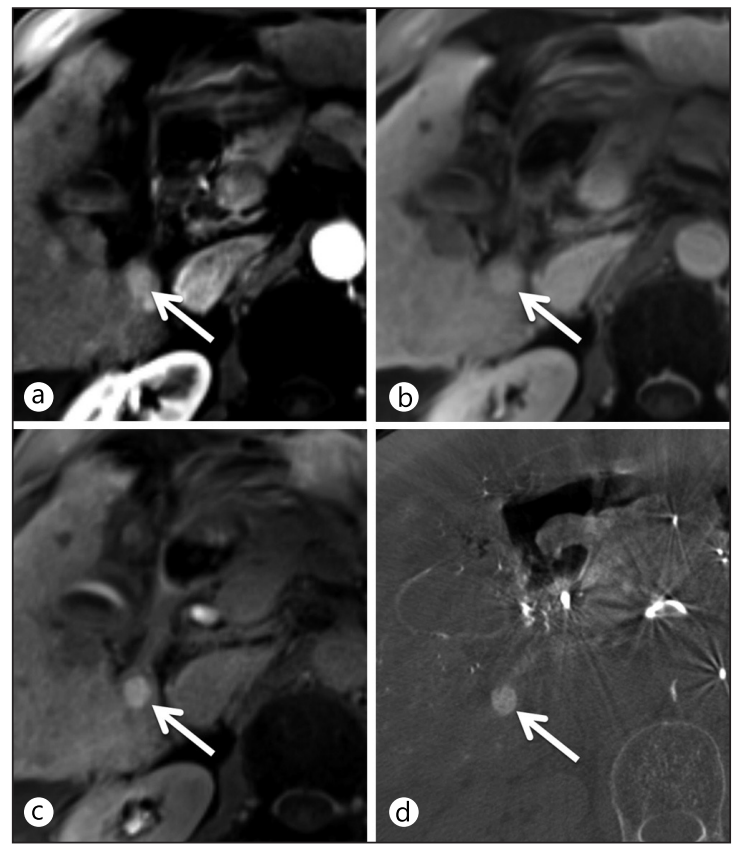

indicates normal biliary function, whereas the presence of sparse bile canaliculi in HCC indicates deficient biliary function [133].

\section{Dual Function Agent-Perfusion and Hepatocyte Function}

The benefit of hepatobiliary phase imaging using hepatocyte-specific contrast agents, such as Sonazoid in US or gadoxetic acid in MRI, is that it enables homogeneous, strong, and prolonged enhancement of the liver parenchyma, which permits better detection of small HCCs. In addition, knowledge regarding the functional status of hepatocytes makes it possible to differentiate between DN and HCC and between HCC and arterioportal shunts [134-138] and to evaluate hepatic function [139-141]. In terms of differential diagnosis of DN and HCC, LGDN shows high signal intensity on hepatobiliary phase images, indicating the presence of functional hepatocytes. HGDN shows decreased signal intensity, and HCC usually shows a clear defect on hepatobiliary phase images.

Recently, investigators reported on the transport mechanism of gadoxetic acid in HCC. Gadoxetic acid is taken up into hepatocytes by organic anion-transporting polypeptide 8 (OATP8) and excreted into the biliary system by multidrug resistance-associated protein 2 (MRP2) [142-144]. As hepatic nodules become more malignant, OATP8 expression usually decreases. Therefore, uptake of gadoxetic acid decreases, resulting in low signal intensity of HGDN and HCC in the hepatobiliary phase whereas high signal intensity of LGDN. However, approximately $10 \%$ of overt HCCs also show iso or high signal intensity in the hepatobiliary phase (fig. 2). This phenomenon can be explained by a genetic alteration that results in the overexpression of OATP8 and MRP2 [142, 145, 146].

\section{Histopathology and Functional Imaging}

The International Pathology Consensus Group for Hepatocellular Neoplasia has published an interesting, evolving concept, i.e., pathological and imaging features define the phases in the evolution of neoplasia in the cirrhotic liver [147]. According to this idea, we must consider not only pathological features but also imaging findings in the evaluation of hepatocarcinogenesis. 
Molecular pathological tools for hepatocarcinogenesis are mainly immunohistochemical stains. An antibody against CD34 is used for sinusoidal capillarization, $\alpha$-smooth muscle actin for unpaired artery, CD68 for Kupffer cells, and CEA for bile canaliculi $[126,133,148]$. For imaging evaluation, various contrast agents, such as extracellular contrast agents, RES agents, and hepatocyte-specific agents, can be used to obtain functional images that reflect molecular pathological features of hepatocarcinogenesis $[100,149]$. As molecular and imaging techniques advance and develop, further studies are needed to correlate pathological and imaging features in hepatocarcinogenesis and document their usefulness in clinical practice.

\section{Current HCC Imaging Guidelines}

Since the announcement of European Association for the Study of the Liver guidelines in 2000 [150], imaging diagnosis of HCC has become more significant. Therefore, use of dynamic US, CT, and MRI for HCC diagnoses has increased while use of biopsies has decreased. According to the American Association for the Study of Liver Diseases (AASLD) guidelines in 2005 and the updated guidelines in 2010, the first step to diagnosing HCC in liver cirrhosis is US. If a nodule is detected on US examination, the next step depends on its size. If the nodule is $<1 \mathrm{~cm}$, follow-up US is recommended, whereas if it is $>1 \mathrm{~cm}$, further contrast-enhanced imaging evaluation such as CT or MRI with typical imaging findings is required for HCC diagnosis $[151,152]$. Typical findings for confirming HCC are high attenuation or signal intensity in the arterial phase and a washout pattern in the portal venous and equilibrium phases. If a nodule does not show a characteristic enhancement pattern, a second contrast-enhanced study with another imaging modality (CT or MRI) should be conducted (fig. 3). According to the Asia Pacific Association for the Study of the Liver (APASL) consensus guidelines in 2010, when a nodule shows hypervascularity in the arterial phase on dynamic CT and/or MRI and washout in the portal venous or delayed phase, a non-invasive diagnosis of HCC can be made, regardless of the size of the lesion. Moreover, when a nodule shows no washout in the portal venous or delayed phase on initial diagnostic tests with dynamic CT and/or MRI, secondary imaging studies such as Sonazoid CEUS or SPIO-MRI can be used instead of biopsy [13, 16]. In summary, there are two differences between AASLD and APASL guidelines. First, there are no size criteria in APASL guidelines. Second, in case of hypovascular nodules on dynamic CT or MRI, secondary diagnostic tests using Kupffer-specific agents instead of biopsy are recommended by APASL guidelines.

There are several problems associated with the current guidelines. Although US is widely used as a screening test for HCC, it has shown limited sensitivity for detecting early-stage HCC. Recent studies revealed that surveillance with US in patients with cirrhosis detected early-stage HCC with a sensitivity of approximately $60 \%[153,154]$. Dynamic CT or MRI may be used as a primary imaging test, but HCC with an atypical enhancement pattern is not rare, making it difficult to differentiate between HCC and other mimickers $[155,156]$. Therefore, guidelines should be continuously re-evaluated and updated.

There are many guidelines from different regions and countries, such as Barcelona Clinic Liver Cancer, APASL, Korean Liver Cancer Study Group, and Japan Society of Hepatology guidelines that address HCC treatment $[15,16,157,158]$. Current treatment methods for HCC include surgery, intervention, and systemic chemotherapy. Recently, local-regional HCC treatment has been progressing rapidly. Local ablation therapies include chemical ablation via ethanol injection and thermal ablation such as radiofrequency ablation (RFA), microwave ablation, and high-intensity focused US [159-163]. For regional (intravascular) therapies, in 
Fig. 3. HCC with atypical enhancing pattern on dynamic CT and typical enhancing pattern on MRI. On dynamic CT images, a 1.5$\mathrm{cm}$ nodule is seen in the caudate lobe of the liver without hypervascularity in the arterial phase (a) and with washout in the delayed phase (b). For this hypovascular nodule, an imaging diagnosis of HCC based on CT findings cannot be made. Dynamic MRI performed as a secondary imaging test, shows nodule enhancement in the arterial phase (c) and washout in the portal-venous phase (d). MRI revealed a typical enhancement pattern of HCC, permitting diagnosis as HCC without biopsy according to the AASLD 2010 guidelines.
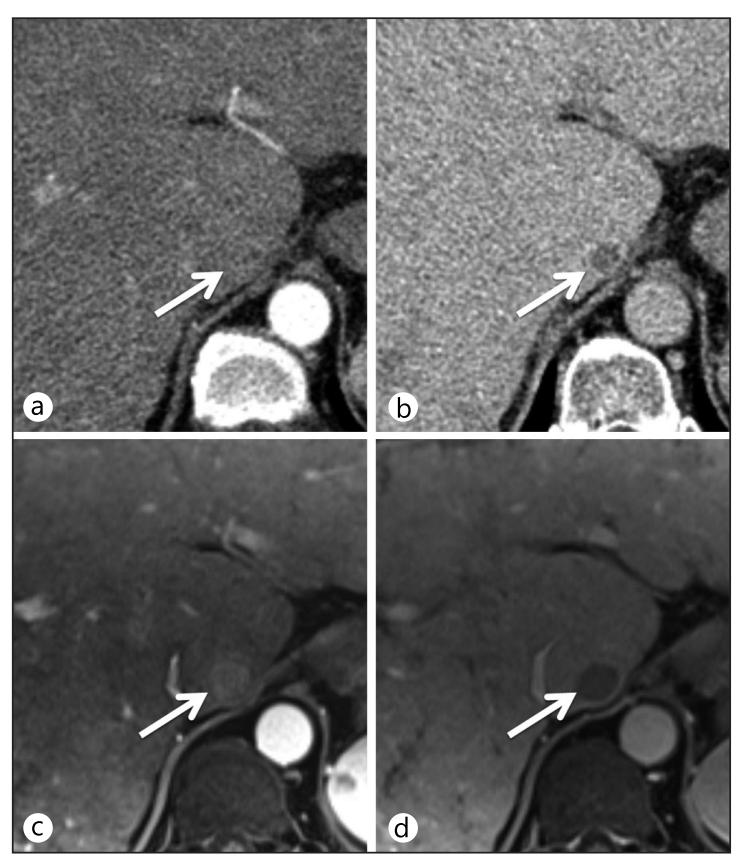

addition to conventional transarterial chemoembolization (TACE), TACE with drug-eluting beads or radioembolization has now been intensively investigated [164-167].

\section{Summary and Future Perspectives of HCC Imaging}

Imaging technology is continuously evolving and becoming more important in HCC diagnosis. In the early 20th century, no useful imaging modality for liver imaging existed. Only simple abdominal radiography was available. However, currently, we have several powerful imaging modalities for HCC. Among these modalities, US is used as a screening technique, and CT is a standard technique widely accepted by clinicians because of its fast speed, wide availability, and good capability for tumor depiction and characterization. The role of MRI is rapidly expanding as a tool complementary to US and CT and as an analytical tool for hepatic nodules.

The paradigm for HCC imaging in the 20th century consisted of gross morphological imaging-pathology correlation. However, the new 21st century paradigm is biochemical, physiological, and functional imaging correlated with molecular diagnostics, in other words, correlation of radiophenotype and molecular phenotype.

In carcinogenesis, from the conversion of a normal cell to invasive cancer, the hallmarks of cancer are manifested from metabolic reprogramming [168, 169]. Therefore, functional imaging would depict these metabolic processes and hallmarks at the tumor level [170].

Radiogenomics was recently introduced as an emerging technology in the field of radiology. Radiogenomics is an integration of in vivo imaging with large-scale gene expression profiles, in other words, an integration of radiophenotypes with molecular phenotypes [171, 172]. As a surrogate for gene expression, radiophenotypes can be used for the molecular assessment of tumors for diagnosis and staging, prediction of prognosis, and determination of HCC treatment [173]. Kuo et al. reported that radiophenotypes of HCC showed an association with drug response gene expression programs [174]. 
Multiparametric imaging is now being actively investigated. By combining the information derived from multiple imaging techniques and modalities, we can obtain more detailed information about tumor biology, thus multiparametric imaging would be useful for drug development and predicting therapeutic efficacy $[170,175]$.

Personalized medicine is the key to future drug development, providing individualized care and treatment based on personal and genetic variations. This new concept of personalized medicine will be wildly applied to HCC [176-179]. The risk of HCC development can be predicted by gene expression or DNA sequencing, and early diagnoses can be made based on various imaging techniques, thereby providing customized treatment for each patient.

In conclusion, future imaging of HCC will include gross morphological imaging, microimaging such as micro-CT/MR/PET, functional imaging, and molecular imaging. The information obtained will be evaluated on the basis of anatomy via dynamic functional imaging, molecular imaging, and genetic imaging with collaboration of physiology, biochemistry, and biology. Therefore, a multidisciplinary, multimodality team approach is mandatory for the diagnosis and treatment of HCC in the future.

\section{Conflict of Interest}

The authors declare no conflict of interest.

\section{References}

1 El-Serag HB: Epidemiology of hepatocellular carcinoma. Clin Liver Dis 2001;5:87-107 vi.

2 El-Serag HB, Mason AC: Rising incidence of hepatocellular carcinoma in the United States. N Engl J Med 1999;340:745-750.

3 Tabor E : Hepatocellular carcinoma: global epidemiology. Dig Liver Dis 2001;33:115-117.

4 Thun MJ, DeLancey JO, Center MM, Jemal A, Ward EM: The global burden of cancer: priorities for prevention. Carcinogenesis 2010;31:100-110.

5 El-Serag HB: Epidemiology of hepatocellular carcinoma in USA. Hepatol Res 2007;37(Suppl 2):S88-S94.

6 El-Serag HB: Hepatocellular carcinoma. N Engl J Med 2011;365:1118-1127.

7 Jemal A, Bray F, Center MM, Ferlay J, Ward E, Forman D: Global cancer statistics. CA Cancer J Clin 2011;61:6990.

8 Yuen MF, Hou JL, Chutaputti A: Hepatocellular carcinoma in the Asia pacific region. J Gastroenterol Hepatol 2009;24:346-353.

9 Nagaoki Y, Hyogo H, Aikata H, Tanaka M, Naeshiro N, Nakahara T, Honda Y, Miyaki D, Kawaoka T, Takaki S, Hiramatsu A, Waki K, Imamura M, Kawakami Y, Takahashi S, Chayama K: Recent trend of clinical features in patients with hepatocellular carcinoma. Hepatol Res. DOI:10.1111/j.1872-034X.2011.00929.x

10 Davila JA, Morgan RO, Richardson PA, Du XL, McGlynn KA, El-Serag HB: Use of surveillance for hepatocellular carcinoma among patients with cirrhosis in the United States. Hepatology 2010;52:132-141.

11 Kim Y, Kim JW, Kuromatsu R, Ahn SH, Torimura T, Sherman M: Controversies in surveillance and early diagnosis of hepatocellular carcinoma. Oncology 2011;81(Suppl 1):56-60.

12 Amarapurkar D, Han KH, Chan HL, Ueno Y: Application of surveillance programs for hepatocellular carcinoma in the Asia-Pacific Region. J Gastroenterol Hepatol 2009;24:955-961.

13 Tan CH, Low SC, Thng CH: APASL and AASLD Consensus Guidelines on Imaging Diagnosis of Hepatocellular Carcinoma: A Review. Int J Hepatol. DOI:10.4061/2011/519783

14 Kudo M, Izumi N, Kokudo N, Matsui O, Sakamoto M, Nakashima O, Kojiro M, Makuuchi M: Management of hepatocellular carcinoma in Japan: Consensus-Based Clinical Practice Guidelines proposed by the Japan Society of Hepatology (JSH) 2010 updated version. Dig Dis 2011;29:339-364.

15 Practice guidelines for management of hepatocellular carcinoma 2009. Korean J Hepatol 2009;15:391-423.

16 Omata M, Lesmana LA, Tateishi R, Chen PJ, Lin SM, Yoshida H, Kudo M, Lee JM, Choi BI, Poon RT, Shiina S, Cheng AL, Jia JD, Obi S, Han KH, Jafri W, Chow P, Lim SG, Chawla YK, Budihusodo U, Gani RA, Lesmana CR, Putranto TA, Liaw YF, Sarin SK: Asian Pacific Association for the Study of the Liver consensus recommendations on hepatocellular carcinoma. Hepatol Int 2010;4:439-474. 
17 Benson AB 3rd, Abrams TA, Ben-Josef E, Bloomston PM, Botha JF, Clary BM, Covey A, Curley SA, D’Angelica MI, Davila R, Ensminger WD, Gibbs JF, Laheru D, Malafa MP, Marrero J, Meranze SG, Mulvihill SJ, Park JO, Posey JA, Sachdev J, Salem R, Sigurdson ER, Sofocleous C, Vauthey JN, Venook AP, Goff LW, Yen Y, Zhu AX: NCCN clinical practice guidelines in oncology: hepatobiliary cancers. J Natl Compr Canc Netw 2009;7:350-391.

18 Giorgio A, Calisti G, di Sarno A, Farella N, de Stefano G, Scognamiglio U, Giorgio V: Characterization of dysplastic nodules, early hepatocellular carcinoma and progressed hepatocellular carcinoma in cirrhosis with contrast-enhanced ultrasound. Anticancer Res 2011;31:3977-3982.

19 Giorgio A, De Stefano G, Coppola C, Ferraioli G, Esposito V, Di Sarno A, Giorgio V, De Stefano M, Sangiovanni V, Liorre G, Del Viscovo L: Contrast-enhanced sonography in the characterization of small hepatocellular carcinomas in cirrhotic patients: comparison with contrast-enhanced ultrafast magnetic resonance imaging. Anticancer Res 2007;27:4263-4269.

20 Inoue T, Kudo M, Maenishi O, Komuta M, Nakashima O, Kojiro M, Maekawa K: Value of liver parenchymal phase contrast-enhanced sonography to diagnose premalignant and borderline lesions and overt hepatocellular carcinoma. AJR Am J Roentgenol 2009;192:698-705.

21 Kim TK, Lee KH, Khalili K, Jang HJ: Hepatocellular nodules in liver cirrhosis: contrast-enhanced ultrasound. Abdom Imaging 2011;36:244-263.

22 Xu HX, Liu GJ, Lu MD, Xie XY, Xu ZF, Zheng YL, Liang JY: Characterization of small focal liver lesions using real-time contrast-enhanced sonography: diagnostic performance analysis in 200 patients. J Ultrasound Med 2006;25:349-361.

23 Jang HJ, Kim TK, Wilson SR: Small nodules $(1-2 \mathrm{~cm})$ in liver cirrhosis: characterization with contrastenhanced ultrasound. Eur J Radiol 2009;72:418-424.

24 Jang HJ, Yu H, Kim TK: Contrast-enhanced ultrasound in the detection and characterization of liver tumors. Cancer Imaging 2009;9:96-103.

25 Arita J, Hasegawa K, Takahashi M, Hata S, Shindoh J, Sugawara Y, Kokudo N: Correlation between contrast-enhanced intraoperative ultrasound using Sonazoid and histologic grade of resected hepatocellular carcinoma. AJR Am J Roentgenol 2011;196:1314-1321.

26 Arita J, Takahashi M, Hata S, Shindoh J, Beck Y, Sugawara Y, Hasegawa K, Kokudo N: Usefulness of contrastenhanced intraoperative ultrasound using Sonazoid in patients with hepatocellular carcinoma. Ann Surg 2011;254:992-999.

27 Hatanaka K, Chung H, Kudo M, Haji S, Minami Y, Maekawa K, Hayaishi S, Nagai T, Takita M, Kudo K, Ueda T, Tatsumi C, Kitai S, Ishikawa E, Yada N, Inoue T, Hagiwara S, Ueshima K: Usefulness of the post-vascular phase of contrast-enhanced ultrasonography with sonazoid in the evaluation of gross types of hepatocellular carcinoma. Oncology 2010;78(Suppl 1):53-59.

28 Korenaga K, Korenaga M, Furukawa M, Yamasaki T, Sakaida I: Usefulness of Sonazoid contrast-enhanced ultrasonography for hepatocellular carcinoma: comparison with pathological diagnosis and superparamagnetic iron oxide magnetic resonance images. J Gastroenterol 2009;44:733-741.

29 Kudo M, Hatanaka K, Maekawa K: Newly developed novel ultrasound technique, defect reperfusion ultrasound imaging, using sonazoid in the management of hepatocellular carcinoma. Oncology 2010;78(Suppl 1):40-45.

30 Sarvazyan AP, Rudenko OV, Swanson SD, Fowlkes JB, Emelianov SY: Shear wave elasticity imaging: a new ultrasonic technology of medical diagnostics. Ultrasound Med Biol 1998;24:1419-1435.

31 Akima T, Tamano M, Hiraishi H: Liver stiffness measured by transient elastography is a predictor of hepatocellular carcinoma development in viral hepatitis. Hepatol Res 2011;41:965-970.

32 Masuzaki R, Tateishi R, Yoshida H, Goto E, Sato T, Ohki T, Imamura J, Goto T, Kanai F, Kato N, Ikeda H, Shiina S, Kawabe T, Omata M: Prospective risk assessment for hepatocellular carcinoma development in patients with chronic hepatitis C by transient elastography. Hepatology 2009;49:1954-1961.

33 Friedrich-Rust M, Nierhoff J, Lupsor M, Sporea I, Fierbinteanu-Braticevici C, Strobel D, Takahashi H, Yoneda M, Suda T, Zeuzem S, Herrmann E: Performance of Acoustic Radiation Force Impulse imaging for the staging of liver fibrosis: a pooled meta-analysis. J Viral Hepat 2012;19:e212-e219.

34 Palmeri ML, Wang MH, Rouze NC, Abdelmalek MF, Guy CD, Moser B, Diehl AM, Nightingale KR: Noninvasive evaluation of hepatic fibrosis using acoustic radiation force-based shear stiffness in patients with nonalcoholic fatty liver disease. J Hepatol 2011;55:666-672.

35 Nakao H, Yoneda M: Liver stiffness measurement using transient elastography and hepatocellular carcinoma. Hepatol Res 2011;41:921-924.

36 Koizumi Y, Hirooka M, Kisaka Y, Konishi I, Abe M, Murakami H, Matsuura B, Hiasa Y, Onji M: Liver fibrosis in patients with chronic hepatitis C: noninvasive diagnosis by means of real-time tissue elastography-establishment of the method for measurement. Radiology 2011;258:610-617.

37 Bavu E, Gennisson JL, Couade M, Bercoff J, Mallet V, Fink M, Badel A, Vallet-Pichard A, Nalpas B, Tanter M, Pol S: Noninvasive in vivo liver fibrosis evaluation using supersonic shear imaging: a clinical study on 113 hepatitis C virus patients. Ultrasound Med Biol 2011;37:1361-1373.

38 Malik R, Lai M, Sadiq A, Farnan R, Mehta S, Nasser I, Challies T, Schuppan D, Afdhal N: Comparison of transient elastography, serum markers and clinical signs for the diagnosis of compensated cirrhosis. J Gastroenterol Hepatol 2010;25:1562-1568.

39 Lee MH, Cheong JY, Um SH, Seo YS, Kim DJ, Hwang SG, Yang JM, Han KH, Cho SW: Comparison of surrogate serum markers and transient elastography (Fibroscan) for assessing cirrhosis in patients with chronic viral hepatitis. Dig Dis Sci 2010;55:3552-3560. 
40 Muller M, Gennisson JL, Deffieux T, Tanter M, Fink M: Quantitative viscoelasticity mapping of human liver using supersonic shear imaging: preliminary in vivo feasibility study. Ultrasound Med Biol 2009;35:219229.

41 Friedrich-Rust M, Ong MF, Herrmann E, Dries V, Samaras P, Zeuzem S, Sarrazin C: Real-time elastography for noninvasive assessment of liver fibrosis in chronic viral hepatitis. AJR Am J Roentgenol 2007;188:758764.

42 Foucher J, Chanteloup E, Vergniol J, Castera L, Le Bail B, Adhoute X, Bertet J, Couzigou P, de Ledinghen V: Diagnosis of cirrhosis by transient elastography (FibroScan): a prospective study. Gut 2006;55:403-408.

43 Elliott ST: Volume ultrasound: the next big thing? Br J Radiol 2008;81:8-9.

44 Wilson SR, Gupta C, Eliasziw M, Andrew A: Volume imaging in the abdomen with ultrasound: how we do it. AJR Am J Roentgenol 2009;193:79-85.

45 Boito SM, Laudy JA, Struijk PC, Stijnen T, Wladimiroff JW: Three-dimensional US assessment of hepatic volume, head circumference, and abdominal circumference in healthy and growth-restricted fetuses. Radiology 2002;223:661-665.

46 Xu HX, Yin XY, Lu MD, Liu GJ, Xu ZF: Estimation of liver tumor volume using a three-dimensional ultrasound volumetric system. Ultrasound Med Biol 2003;29:839-846.

47 Park SH, Choi BI, Han JK, Yoon CJ, Lee JW, Kim SS, Han H: Volumetric tumor measurement using threedimensional ultrasound: in vitro phantom study on measurement accuracy under various scanning conditions. Ultrasound Med Biol 2004;30:27-34.

48 Kim SJ, Choi BI, Kim SH, Lee JY: Three-dimensional imaging for hepatobiliary and pancreatic diseases: Emphasis on clinical utility. Indian J Radiol Imaging 2009;19:7-15.

49 Downey DB, Fenster A, Williams JC: Clinical utility of three-dimensional US. Radiographics 2000;20:559571.

50 Xu HX, Liu L, Lu MD, Li HP, Liu GJ, Li JP: Three-dimensional power Doppler imaging in depicting vascularity in hepatocellular carcinoma. J Ultrasound Med 2003;22:1147-1154.

51 Liang JD, Yang PM, Liang PC, Huang GT, Sheu JC, Chen DS: Three-dimensional power Doppler ultrasonography for demonstrating associated arteries of hepatocellular carcinoma. J Formos Med Assoc 2003;102:367374.

52 Sato S, Yoshida H, Teratani T, Obi S, Koike Y, Shiina S, Omata M: Three-dimensional power Doppler ultrasonography for hepatocellular carcinoma: a comparison with angiography? Hepatogastroenterology 2005;52:72-75.

53 Numata K, Fukuda H, Ohto M, Itou R, Nozaki A, Kondou M, Morimoto M, Karasawa E, Tanaka K: Evaluation of the therapeutic efficacy of high-intensity focused ultrasound ablation of hepatocellular carcinoma by three-dimensional sonography with a perflubutane-based contrast agent. Eur J Radiol 2010;75:e67-e75.

54 Luo W, Numata K, Morimoto M, Oshima T, Ueda M, Okada M, Takebayashi S, Zhou X, Tanaka K: Role of Sonazoid-enhanced three-dimensional ultrasonography in the evaluation of percutaneous radiofrequency ablation of hepatocellular carcinoma. Eur J Radiol 2010;75:91-97.

55 Xu HX, Lu MD, Xie XH, Xie XY, Kuang M, Xu ZF, Liu GJ, Wang Z, Chen LD, Lin MX: Treatment response evaluation with three-dimensional contrast-enhanced ultrasound for liver cancer after local therapies. Eur J Radiol 2010;76:81-88.

56 Graser A, Johnson TR, Chandarana H, Macari M: Dual energy CT: preliminary observations and potential clinical applications in the abdomen. Eur Radiol 2009;19:13-23.

57 Yeh BM, Shepherd JA, Wang ZJ, Teh HS, Hartman RP, Prevrhal S: Dual-energy and low-kVp CT in the abdomen. AJR Am J Roentgenol 2009;193:47-54.

58 Altenbernd J, Heusner TA, Ringelstein A, Ladd SC, Forsting M, Antoch G: Dual-energy-CT of hypervascular liver lesions in patients with HCC: investigation of image quality and sensitivity. Eur Radiol 2011;21:738743.

59 Okada M, Kim T, Murakami T: Hepatocellular nodules in liver cirrhosis: state of the art CT evaluation (perfusion CT/volume helical shuttle scan/dual-energy CT, etc.). Abdom Imaging 2011;36:273-281.

60 Murakami T, Imai Y, Okada M, Hyodo T, Lee WJ, Kim MJ, Kim T, Choi BI: Ultrasonography, computed tomography and magnetic resonance imaging of hepatocellular carcinoma: toward improved treatment decisions. Oncology 2011;81(Suppl 1):86-99.

61 Schindera ST, Nelson RC, Mukundan S Jr, Paulson EK, Jaffe TA, Miller CM, DeLong DM, Kawaji K, Yoshizumi TT, Samei E: Hypervascular liver tumors: low tube voltage, high tube current multi-detector row CT for enhanced detection-phantom study. Radiology 2008;246:125-132.

62 Kim KS, Lee JM, Kim SH, Kim KW, Kim SJ, Cho SH, Han JK, Choi BI: Image fusion in dual energy computed tomography for detection of hypervascular liver hepatocellular carcinoma: phantom and preliminary studies. Invest Radiol 2010;45:149-157.

63 Ehman EC, Guimaraes LS, Fidler JL, Takahashi N, Ramirez-Giraldo JC, Yu L, Manduca A, Huprich JE, McCollough CH, Holmes D 3rd, Harmsen WS, Fletcher JG: Noise reduction to decrease radiation dose and improve conspicuity of hepatic lesions at contrast-enhanced $80-\mathrm{kV}$ hepatic CT using projection space denoising. AJR Am J Roentgenol 2012;198:405-411.

64 Holmes DR 3rd, Fletcher JG, Apel A, Huprich JE, Siddiki H, Hough DM, Schmidt B, Flohr TG, Robb R, McCollough C, Wittmer M, Eusemann C: Evaluation of non-linear blending in dual-energy computed tomography. Eur J Radiol 2008;68:409-413.

65 Pandharipande PV, Krinsky GA, Rusinek H, Lee VS: Perfusion imaging of the liver: current challenges and future goals. Radiology 2005;234:661-673. 
66 Zhu AX, Holalkere NS, Muzikansky A, Horgan K, Sahani DV: Early antiangiogenic activity of bevacizumab evaluated by computed tomography perfusion scan in patients with advanced hepatocellular carcinoma. Oncologist 2008;13:120-125.

67 Petralia G, Fazio N, Bonello L, D’Andrea G, Radice D, Bellomi M: Perfusion computed tomography in patients with hepatocellular carcinoma treated with thalidomide: initial experience. J Comput Assist Tomogr 2011;35:195-201.

68 Jiang T, Kambadakone A, Kulkarni NM, Zhu AX, Sahani DV: Monitoring response to antiangiogenic treatment and predicting outcomes in advanced hepatocellular carcinoma using image biomarkers, CT perfusion, tumor density, and tumor size (RECIST). Invest Radiol 2012;47:11-17.

69 Maksimovic O, Schraml C, Hartmann JT, Bitzer M, Claussen CD, Pintoffl J, Horger M: Evaluation of response in malignant tumors treated with the multitargeted tyrosine kinase inhibitor sorafenib: a multitechnique imaging assessment. AJR Am J Roentgenol 2010;194:5-14.

70 Meijerink MR, van Waesberghe JH, van der Weide L, van den Tol P, Meijer S, Comans EF, Golding RP, van Kuijk C: Early detection of local RFA site recurrence using total liver volume perfusion CT initial experience. Acad Radiol 2009;16:1215-1222.

71 Choi SH, Chung JW, Kim HC, Baek JH, Park CM, Jun S, Kim MU, Lee ES, Cho HR, Jae HJ, Lee W, Park JH: The role of perfusion CT as a follow-up modality after transcatheter arterial chemoembolization: an experimental study in a rabbit model. Invest Radiol 2010;45:427-436.

72 Yang L, Zhang XM, Zhou XP, Tang W, Guan YS, Zhai ZH, Dong GL: Correlation between tumor perfusion and lipiodol deposition in hepatocellular carcinoma after transarterial chemoembolization. J Vasc Interv Radiol 2010;21:1841-1846.

73 Ippolito D, Bonaffini PA, Ratti L, Antolini L, Corso R, Fazio F, Sironi S: Hepatocellular carcinoma treated with transarterial chemoembolization: dynamic perfusion-CT in the assessment of residual tumor. World J Gastroenterol 2010;16:5993-6000.

74 Goh V, Padhani AR: Imaging tumor angiogenesis: functional assessment using MDCT or MRI? Abdom Imaging 2006;31:194-199.

75 ChoiBI: Advances of imaging for hepatocellular carcinoma. Oncology 2010;78(Suppl 1):46-52.

76 Koh DM, Collins DJ: Diffusion-weighted MRI in the body: applications and challenges in oncology. AJR Am J Roentgenol 2007;188:1622-1635.

77 Taouli B, Ehman RL, Reeder SB: Advanced MRI methods for assessment of chronic liver disease. AJR Am J Roentgenol 2009;193:14-27.

78 Lee JM, Choi BI: Hepatocellular nodules in liver cirrhosis: MR evaluation. Abdom Imaging 2011;36:282289.

79 Park MS, Kim S, Patel J, Hajdu CH, Do RK, Mannelli L, Babb JS, Taouli B: Hepatocellular carcinoma: Detection with diffusion-weighted vs. contrast-enhanced MRI in pre-transplant patients. Hepatology DOI: 10.1002/hep.25681.

$80 \mathrm{Xu}$ PJ, Yan FH, Wang JH, Lin J, Ji Y: Added value of breathhold diffusion-weighted MRI in detection of small hepatocellular carcinoma lesions compared with dynamic contrast-enhanced MRI alone using receiver operating characteristic curve analysis. J Magn Reson Imaging 2009;29:341-349.

81 Yu JS, Chung JJ, Kim JH, Cho ES, Kim DJ, Ahn JH, Kim KW: Detection of small intrahepatic metastases of hepatocellular carcinomas using diffusion-weighted imaging: comparison with conventional dynamic MRI. Magn Reson Imaging 2011;29:985-992.

82 An C, Park MS, Jeon HM, Kim YE, Chung WS, Chung YE, Kim MJ, Kim KW: Prediction of the histopathological grade of hepatocellular carcinoma using qualitative diffusion-weighted, dynamic, and hepatobiliary phase MRI. Eur Radiol DOI: 10.1007/s00330-012-2421-6.

83 Lee MH, Kim SH, Park MJ, Park CK, Rhim H: Gadoxetic acid-enhanced hepatobiliary phase MRI and highb-value diffusion-weighted imaging to distinguish well-differentiated hepatocellular carcinomas from benign nodules in patients with chronic liver disease. AJR Am J Roentgenol 2011;197:W868-875.

84 Nakanishi M, Chuma M, Hige S, Omatsu T, Yokoo H, Nakanishi K, Kamiyama T, Kubota K, Haga H, Matsuno Y, Onodera Y, Kato M, Asaka M: Relationship between diffusion-weighted magnetic resonance imaging and histological tumor grading of hepatocellular carcinoma. Ann Surg Oncol 2012;19:1302-1309.

85 Nishie A, Tajima T, Asayama Y, Ishigami K, Kakihara D, Nakayama T, Takayama Y, Okamoto D, Fujita N, Taketomi A, Yoshimitsu K, Honda H: Diagnostic performance of apparent diffusion coefficient for predicting histological grade of hepatocellular carcinoma. Eur J Radiol 2011;80:e29-e33.

86 Bonekamp S, Jolepalem P, Lazo M, Gulsun MA, Kiraly AP, Kamel IR: Hepatocellular carcinoma: response to TACE assessed with semiautomated volumetric and functional analysis of diffusion-weighted and contrast-enhanced MR imaging data. Radiology 2011;260:752-761.

87 Babsky AM, Ju S, George B, Bennett S, Huang M, Jayaram HN, McLennan G, Bansal N: Predicting response to benzamide riboside chemotherapy in hepatocellular carcinoma using apparent diffusion coefficient of water. Anticancer Res 2011;31:2045-2051.

88 Kubota K, Yamanishi T, Itoh S, Murata Y, Miyatake K, Yasunami H, Morio K, Hamada N, Nishioka A, Ogawa Y: Role of diffusion-weighted imaging in evaluating therapeutic efficacy after transcatheter arterial chemoembolization for hepatocellular carcinoma. Oncol Rep 2010;24:727-732.

89 Goshima S, Kanematsu M, Kondo H, Yokoyama R, Tsuge Y, Shiratori Y, Onozuka M, Moriyama N: Evaluating local hepatocellular carcinoma recurrence post-transcatheter arterial chemoembolization: is diffusionweighted MRI reliable as an indicator? J Magn Reson Imaging 2008;27:834-839. 
90 Schraml C, Schwenzer NF, Martirosian P, Bitzer M, Lauer U, Claussen CD, Horger M: Diffusion-weighted MRI of advanced hepatocellular carcinoma during sorafenib treatment: initial results. AJR Am J Roentgenol 2009;193:W301-7.

91 Asbach P, Klatt D, Schlosser B, Biermer M, Muche M, Rieger A, Loddenkemper C, Somasundaram R, Berg T, Hamm B, Braun J, Sack I: Viscoelasticity-based staging of hepatic fibrosis with multifrequency MR elastography. Radiology 2010;257:80-86.

92 Rustogi R, Horowitz J, Harmath C, Wang Y, Chalian H, Ganger DR, Chen ZE, Bolster BD Jr, Shah S, Miller FH: Accuracy of MR elastography and anatomic MR imaging features in the diagnosis of severe hepatic fibrosis and cirrhosis. J Magn Reson Imaging DOI: 10.1002/jmri.23585.

93 Wang Y, Ganger DR, Levitsky J, Sternick LA, McCarthy RJ, Chen ZE, Fasanati CW, Bolster B, Shah S, Zuehlsdorff S, Omary RA, Ehman RL, Miller FH: Assessment of chronic hepatitis and fibrosis: comparison of MR elastography and diffusion-weighted imaging. AJR Am J Roentgenol 2011;196:553-561.

94 Yin M, Talwalkar JA, Glaser KJ, Manduca A, Grimm RC, Rossman PJ, Fidler JL, Ehman RL: Assessment of hepatic fibrosis with magnetic resonance elastography. Clin Gastroenterol Hepatol 2007;5:1207-1213 e1202.

95 Hines CD, Bley TA, Lindstrom MJ, Reeder SB: Repeatability of magnetic resonance elastography for quantification of hepatic stiffness. J Magn Reson Imaging 2010;31:725-731.

96 Huwart L, Sempoux C, Salameh N, Jamart J, Annet L, Sinkus R, Peeters F, ter Beek LC, Horsmans Y, Van Beers BE: Liver fibrosis: noninvasive assessment with MR elastography versus aspartate aminotransferase-toplatelet ratio index. Radiology 2007;245:458-466.

97 Huwart L, Sempoux C, Vicaut E, Salameh N, Annet L, Danse E, Peeters F, ter Beek LC, Rahier J, Sinkus R, Horsmans Y, Van Beers BE: Magnetic resonance elastography for the noninvasive staging of liver fibrosis. Gastroenterology 2008;135:32-40.

98 Kim BH, Lee JM, Lee YJ, Lee KB, Suh KS, Han JK, Choi BI: MR elastography for noninvasive assessment of hepatic fibrosis: experience from a tertiary center in Asia. J Magn Reson Imaging 2011;34:1110-1116.

99 Venkatesh SK, Yin M, Glockner JF, Takahashi N, Araoz PA, Talwalkar JA, Ehman RL: MR elastography of liver tumors: preliminary results. AJR Am J Roentgenol 2008;190:1534-1540.

100 Goodwin MD, Dobson JE, Sirlin CB, Lim BG, Stella DL: Diagnostic challenges and pitfalls in MR imaging with hepatocyte-specific contrast agents. Radiographics 2011;31:1547-1568.

101 Lee JM, Zech CJ, Bolondi L, Jonas E, Kim MJ, Matsui O, Merkle EM, Sakamoto M, Choi BI: Consensus report of the 4th International Forum for Gadolinium-Ethoxybenzyl-Diethylenetriamine Pentaacetic Acid Magnetic Resonance Imaging. Korean J Radiol 2011;12:403-415.

102 Fidler J, Hough D: Hepatocyte-specific magnetic resonance imaging contrast agents. Hepatology 2011;53:678-682.

103 Kim TK, Lee KH, Jang HJ, Haider MA, Jacks LM, Menezes RJ, Park SH, Yazdi L, Sherman M, Khalili K: Analysis of gadobenate dimeglumine-enhanced MR findings for characterizing small $(1-2-\mathrm{cm})$ hepatic nodules in patients at high risk for hepatocellular carcinoma. Radiology 2011;259:730-738.

104 Park Y, Kim SH, Jeon YH, Lee J, Kim MJ, Choi D, Lee WJ, Kim H, Koo JH, Lim HK: Gadoxetic acid (Gd-EOBDTPA)-enhanced MRI versus gadobenate dimeglumine (Gd-BOPTA)-enhanced MRI for preoperatively detecting hepatocellular carcinoma: an initial experience. Korean J Radiol 2010;11:433-440.

105 Marin D, Di Martino M, Guerrisi A, De Filippis G, Rossi M, Ginanni Corradini S, Masciangelo R, Catalano C, Passariello R: Hepatocellular carcinoma in patients with cirrhosis: qualitative comparison of gadobenate dimeglumine-enhanced MR imaging and multiphasic 64-section CT. Radiology 2009;251:85-95.

106 Kim YK, Kim CS, Chung GH, Han YM, Lee SY, Chon SB, Lee JM: Comparison of gadobenate dimeglumineenhanced dynamic MRI and 16-MDCT for the detection of hepatocellular carcinoma. AJR Am J Roentgenol 2006;186:149-157.

107 Vogl TJ, Stupavsky A, Pegios W, Hammerstingl R, Mack M, Diebold T, Lodemann KP, Neuhaus P, Felix R: Hepatocellular carcinoma: evaluation with dynamic and static gadobenate dimeglumine-enhanced MR imaging and histopathologic correlation. Radiology 1997;205:721-728.

108 Hwang J, Kim SH, Lee MW, Lee JY: Small $(<=2 \mathrm{~cm})$ hepatocellular carcinoma in patients with chronic liver disease: comparison of gadoxetic acid-enhanced 3.0 T MRI and multiphasic 64-MDCT. Br J Radiol DOI: $10.1259 / \mathrm{bjr} / 27727228$

109 Kim SH, Lee J, Kim MJ, Jeon YH, Park Y, Choi D, Lee WJ, Lim HK: Gadoxetic acid-enhanced MRI versus triple-phase MDCT for the preoperative detection of hepatocellular carcinoma. AJR Am J Roentgenol 2009;192:1675-1681.

110 Rhee H, Kim MJ, Park YN, Choi JS, Kim KS: Gadoxetic acid-enhanced MRI findings of early hepatocellular carcinoma as defined by new histologic criteria. J Magn Reson Imaging 2012;35:393-398.

111 Yong TW, Yuan ZZ, Jun Z, Lin Z, He WZ, Juanqi Z: Sensitivity of PET/MR images in liver metastases from colorectal carcinoma. Hell J Nucl Med 2011;14:264-268.

112 Wissmeyer M, Heinzer S, Majno P, Buchegger F, Zaidi H, Garibotto V, Viallon M, Becker CD, Ratib O, Terraz S: Y Time-of-flight PET/MR on a hybrid scanner following liver radioembolisation (SIRT). Eur J Nucl Med Mol Imaging 2011;38:1744-1745.

113 Kunishi Y, Numata K, Morimoto M, Okada M, Kaneko T, Maeda S, Tanaka K: Efficacy of fusion imaging combining sonography and hepatobiliary phase MRI with Gd-EOB-DTPA to detect small hepatocellular carcinoma. AJR Am J Roentgenol 2012;198:106-114.

114 Sandulescu DL, Dumitrescu D, Rogoveanu I, Saftoiu A: Hybrid ultrasound imaging techniques (fusion imaging). World J Gastroenterol 2011;17:49-52. 
115 Fukuda H, Numata K, Nozaki A, Morimoto M, Kondo M, Tanaka K, Maeda S, Yamagata J, Ohto M, Ito R, Sakamoto A, Zhu H, Wang ZB: Usefulness of US-CT 3D dual imaging for the planning and monitoring of hepatocellular carcinoma treatment using HIFU. Eur J Radiol 2011;80:e306-e310.

116 Krücker J, Xu S, Venkatesan A, Locklin JK, Amalou H, Glossop N, Wood BJ: Clinical utility of real-time fusion guidance for biopsy and ablation. J Vasc Interv Radiol 2011;22:515-524.

117 Choi BI, Takayasu K, Han MC: Small hepatocellular carcinomas and associated nodular lesions of the liver: pathology, pathogenesis, and imaging findings. AJR Am J Roentgenol 1993;160:1177-1187.

118 Kudo M: Multistep human hepatocarcinogenesis: correlation of imaging with pathology. J Gastroenterol 2009;44(Suppl 19):112-118.

119 Park YN, Yang CP, Fernandez GJ, Cubukcu O, Thung SN, Theise ND: Neoangiogenesis and sinusoidal "capillarization" in dysplastic nodules of the liver. Am J Surg Pathol 1998;22:656-662.

120 Roskams T, Kojiro M: Pathology of early hepatocellular carcinoma: conventional and molecular diagnosis. Semin Liver Dis 2010;30:17-25.

121 Tajima T, Honda H, Taguchi K, Asayama Y, Kuroiwa T, Yoshimitsu K, Irie H, Aibe H, Shimada M, Masuda K: Sequential hemodynamic change in hepatocellular carcinoma and dysplastic nodules: CT angiography and pathologic correlation. AJR Am J Roentgenol 2002;178:885-897.

122 Thorgeirsson SS, Grisham JW: Molecular pathogenesis of human hepatocellular carcinoma. Nat Genet 2002;31:339-346.

123 Matsui O, Kobayashi S, Sanada J, Kouda W, Ryu Y, Kozaka K, Kitao A, Nakamura K, Gabata T: Hepatocelluar nodules in liver cirrhosis: hemodynamic evaluation (angiography-assisted CT) with special reference to multi-step hepatocarcinogenesis. Abdom Imaging 2011;36:264-272.

124 Honda H, Tajima T, Kajiyama K, Kuroiwa T, Yoshimitsu K, Irie H, Aibe H, Shimada M, Masuda K: Vascular changes in hepatocellular carcinoma: correlation of radiologic and pathologic findings. AJR Am J Roentgenol 1999;173:1213-1217.

125 Hayashi M, Matsui O, Ueda K, Kawamori Y, Kadoya M, Yoshikawa J, Gabata T, Takashima T, Nonomura A, Nakanuma Y: Correlation between the blood supply and grade of malignancy of hepatocellular nodules associated with liver cirrhosis: evaluation by CT during intraarterial injection of contrast medium. AJR Am J Roentgenol 1999;172:969-976.

126 Liu K, He X, Lei XZ, Zhao LS, Tang H, Liu L, Lei BJ: Pathomorphological study on location and distribution of Kupffer cells in hepatocellular carcinoma. World J Gastroenterol 2003;9:1946-1949.

127 Tanaka M, Nakashima O, Wada Y, Kage M, Kojiro M: Pathomorphological study of Kupffer cells in hepatocellular carcinoma and hyperplastic nodular lesions in the liver. Hepatology 1996;24:807-812.

128 Park HS, Lee JM, Kim SH, Chang S, Kim SJ, Han JK, Choi BI: Differentiation of well-differentiated hepatocellular carcinomas from other hepatocellular nodules in cirrhotic liver: value of SPIO-enhanced MR imaging at 3.0 Tesla. J Magn Reson Imaging 2009;29:328-335.

129 Tanimoto A, Kuribayashi S: Application of superparamagnetic iron oxide to imaging of hepatocellular carcinoma. Eur J Radiol 2006;58:200-216.

130 Yoo HJ, Lee JM, Lee JY, Kim SH, Kim SJ, Han JK, Choi BI: Additional value of SPIO-enhanced MR imaging for the noninvasive imaging diagnosis of hepatocellular carcinoma in cirrhotic liver. Invest Radiol 2009;44:800-807.

131 Yoon MA, Kim SH, Park HS, Lee DH, Lee JY, Han JK, Choi BI: Value of dual contrast liver MRI at 3.0 T in differentiating well-differentiated hepatocellular carcinomas from dysplastic nodules: preliminary results of multivariate analysis. Invest Radiol 2009;44:641-649.

132 Lim JH, Choi D, Cho SK, Kim SH, Lee WJ, Lim HK, Park CK, Paik SW, Kim YI: Conspicuity of hepatocellular nodular lesions in cirrhotic livers at ferumoxides-enhanced MR imaging: importance of Kupffer cell number. Radiology 2001;220:669-676.

133 Bartolozzi C, Crocetti L, Lencioni R, Cioni D, Della Pina C, Campani D: Biliary and reticuloendothelial impairment in hepatocarcinogenesis: the diagnostic role of tissue-specific MR contrast media. Eur Radiol 2007;17:2519-2530.

134 Sano K, Ichikawa T, Motosugi U, Sou H, Muhi AM, Matsuda M, Nakano M, Sakamoto M, Nakazawa T, Asakawa M, Fujii H, Kitamura T, Enomoto N, Araki T: Imaging study of early hepatocellular carcinoma: usefulness of gadoxetic acid-enhanced MR imaging. Radiology 2011;261:834-844.

135 Motosugi U, Ichikawa T, Sou H, Sano K, Tominaga L, Muhi A, Araki T: Distinguishing hypervascular pseudolesions of the liver from hypervascular hepatocellular carcinomas with gadoxetic acid-enhanced MR imaging. Radiology 2010;256:151-158.

136 Sun HY, Lee JM, Shin CI, Lee DH, Moon SK, Kim KW, Han JK, Choi BI: Gadoxetic acid-enhanced magnetic resonance imaging for differentiating small hepatocellular carcinomas ( $<$ or $=2 \mathrm{~cm}$ in diameter) from arterial enhancing pseudolesions: special emphasis on hepatobiliary phase imaging. Invest Radiol 2010;45:96-103.

137 Inoue T, Kudo M, Hatanaka K, Takahashi S, Kitai S, Ueda T, Ishikawa E, Hagiwara S, Minami Y, Chung $\mathrm{H}$, Ueshima K, Maekawa K: Imaging of hepatocellular carcinoma: qualitative and quantitative analysis of postvascular phase contrast-enhanced ultrasonography with sonazoid. Comparison with superparamagnetic iron oxide magnetic resonance images. Oncology 2008;75(Suppl 1):48-54.

138 Sugimoto K, Moriyasu F, Saito K, Taira J, Saguchi T, Yoshimura N, Oshiro H, Imai Y, Shiraishi J: Comparison of kupffer-phase sonazoid-enhanced sonography and hepatobiliary-phase gadoxetic Acid-enhanced magnetic resonance imaging of hepatocellular carcinoma and correlation with histologic grading. J Ultrasound Med 2012;31:529-538. 
139 Motosugi U, Ichikawa T, Sou H, Sano K, Tominaga L, Kitamura T, Araki T: Liver parenchymal enhancement of hepatocyte-phase images in Gd-EOB-DTPA-enhanced MR imaging: which biological markers of the liver function affect the enhancement? J Magn Reson Imaging 2009;30:1042-1046.

140 Motosugi U, Ichikawa T, Oguri M, Sano K, Sou H, Muhi A, Matsuda M, Fujii H, Enomoto N, Araki T: Staging liver fibrosis by using liver-enhancement ratio of gadoxetic acid-enhanced MR imaging: comparison with aspartate aminotransferase-to-platelet ratio index. Magn Reson Imaging 2011;29:1047-1052.

141 Katsube T, Okada M, Kumano S, Hori M, Imaoka I, Ishii K, Kudo M, Kitagaki H, Murakami T: Estimation of liver function using T1 mapping on Gd-EOB-DTPA-enhanced magnetic resonance imaging. Invest Radiol 2011;46:277-283.

142 Kitao A, Zen Y, Matsui O, Gabata T, Kobayashi S, Koda W, Kozaka K, Yoneda N, Yamashita T, Kaneko S, Nakanuma Y: Hepatocellular carcinoma: signal intensity at gadoxetic acid-enhanced MR Imaging-correlation with molecular transporters and histopathologic features. Radiology 2010;256:817-826.

143 Kitao A, Matsui O, Yoneda N, Kozaka K, Shinmura R, Koda W, Kobayashi S, Gabata T, Zen Y, Yamashita T, Kaneko S, Nakanuma Y: The uptake transporter OATP8 expression decreases during multistep hepatocarcinogenesis: correlation with gadoxetic acid enhanced MR imaging. Eur Radiol 2011;21:2056-2066.

144 Narita M, Hatano E, Arizono S, Miyagawa-Hayashino A, Isoda H, Kitamura K, Taura K, Yasuchika K, Nitta T, Ikai I, Uemoto S: Expression of OATP1B3 determines uptake of Gd-EOB-DTPA in hepatocellular carcinoma. J Gastroenterol 2009;44:793-798.

145 Pastor CM: Gadoxetic acid-enhanced hepatobiliary phase MR imaging: cellular insight. Radiology 2010;257:589.

146 Tsuboyama T, Onishi H, Kim T, Akita H, Hori M, Tatsumi M, Nakamoto A, Nagano H, Matsuura N, Wakasa K, Tomoda K: Hepatocellular carcinoma: hepatocyte-selective enhancement at gadoxetic acid-enhanced MR imaging-correlation with expression of sinusoidal and canalicular transporters and bile accumulation. Radiology 2010;255:824-833.

147 Pathologic diagnosis of early hepatocellular carcinoma: a report of the international consensus group for hepatocellular neoplasia. Hepatology 2009;49:658-664.

148 Nakamura K, Zen Y, Sato Y, Kozaka K, Matsui O, Harada K, Nakanuma Y: Vascular endothelial growth factor, its receptor Flk-1, and hypoxia inducible factor-1alpha are involved in malignant transformation in dysplastic nodules of the liver. Hum Pathol 2007;38:1532-1546.

149 Weinmann HJ, Ebert W, Misselwitz B, Schmitt-Willich H: Tissue-specific MR contrast agents. Eur J Radiol 2003;46:33-44.

150 Bruix J, Sherman M, Llovet JM, Beaugrand M, Lencioni R, Burroughs AK, Christensen E, Pagliaro L, Colombo M, Rodes J: Clinical management of hepatocellular carcinoma. Conclusions of the Barcelona-2000 EASL conference. European Association for the Study of the Liver. J Hepatol 2001;35:421-430.

151 Bruix J, Sherman M: Management of hepatocellular carcinoma. Hepatology 2005;42:1208-1236.

152 Bruix J, Sherman M: Management of hepatocellular carcinoma: an update. Hepatology 2011;53:1020-1022.

153 Singal A, Volk ML, Waljee A, Salgia R, Higgins P, Rogers MA, Marrero JA: Meta-analysis: surveillance with ultrasound for early-stage hepatocellular carcinoma in patients with cirrhosis. Aliment Pharmacol Ther 2009;30:37-47.

154 Daniele B, Bencivenga A, Megna AS, Tinessa V: Alpha-fetoprotein and ultrasonography screening for hepatocellular carcinoma. Gastroenterology 2004;127:S108-S112.

155 Yoon SH, Lee JM, So YH, Hong SH, Kim SJ, Han JK, Choi BI: Multiphasic MDCT enhancement pattern of hepatocellular carcinoma smaller than $3 \mathrm{~cm}$ in diameter: tumor size and cellular differentiation. AJR Am J Roentgenol 2009;193:W482-9.

156 Golfieri R, Renzulli M, Lucidi V, Corcioni B, Trevisani F, Bolondi L: Contribution of the hepatobiliary phase of Gd-EOB-DTPA-enhanced MRI to Dynamic MRI in the detection of hypovascular small $(</=2 \mathrm{~cm}) \mathrm{HCC}$ in cirrhosis. Eur Radiol 2011;21:1233-1242.

157 Kudo M, Han KH, Kokudo N, Cheng AL, Choi BI, Furuse J, Izumi N, Park JW, Poon RT, Sakamoto M: Liver Cancer Working Group report. Jpn J Clin Oncol 2010;40(Suppl 1):i19-i27.

158 Llovet JM, Di Bisceglie AM, Bruix J, Kramer BS, Lencioni R, Zhu AX, Sherman M, Schwartz M, Lotze M, Talwalkar J, Gores GJ: Design and endpoints of clinical trials in hepatocellular carcinoma. J Natl Cancer Inst 2008;100:698-711.

159 Minami Y, Kudo M: Radiofrequency ablation of hepatocellular carcinoma: a literature review. Int J Hepatol. DOI: $10.4061 / 2011 / 104685$

160 Livraghi T, Giorgio A, Marin G, Salmi A, de Sio I, Bolondi L, Pompili M, Brunello F, Lazzaroni S, Torzilli G, et al: Hepatocellular carcinoma and cirrhosis in 746 patients: long-term results of percutaneous ethanol injection. Radiology 1995;197:101-108.

161 Shiina S, Tagawa K, Niwa Y, Unuma T, Komatsu Y, Yoshiura K, Hamada E, Takahashi M, Shiratori Y, Terano A, et al: Percutaneous ethanol injection therapy for hepatocellular carcinoma: results in 146 patients. AJR Am J Roentgenol 1993;160:1023-1028.

162 Cho YK, Rhim H, Noh S: Radiofrequency ablation versus surgical resection as primary treatment of hepatocellular carcinoma meeting the Milan criteria: a systematic review. J Gastroenterol Hepatol 2011;26:13541360.

163 Zhang L, Zhu H, Jin C, Zhou K, Li K, Su H, Chen W, Bai J, Wang Z: High-intensity focused ultrasound (HIFU): effective and safe therapy for hepatocellular carcinoma adjacent to major hepatic veins. Eur Radiol 2009;19:437-445. 
164 Song MJ, Park CH, Kim JD, Kim HY, Bae SH, Choi JY, Yoon SK, Chun HJ, Choi BG, Lee HG: Drug-eluting bead loaded with doxorubicin versus conventional Lipiodol-based transarterial chemoembolization in the treatment of hepatocellular carcinoma: a case-control study of Asian patients. Eur J Gastroenterol Hepatol 2011;23:521-527.

165 Poon RT, Tso WK, Pang RW, Ng KK, Woo R, Tai KS, Fan ST: A phase I/II trial of chemoembolization for hepatocellular carcinoma using a novel intra-arterial drug-eluting bead. Clin Gastroenterol Hepatol 2007;5:1100-1108.

166 Sangro B, Inarrairaegui M, Bilbao JI: Radioembolization for hepatocellular carcinoma. J Hepatol 2012;56:464-473.

167 Salem R, Lewandowski RJ, Mulcahy MF, Riaz A, Ryu RK, Ibrahim S, Atassi B, Baker T, Gates V, Miller FH, Sato KT, Wang E, Gupta R, Benson AB, Newman SB, Omary RA, Abecassis M, Kulik L: Radioembolization for hepatocellular carcinoma using Yttrium-90 microspheres: a comprehensive report of long-term outcomes. Gastroenterology 2010;138:52-64.

168 Gatenby RA, Gillies RJ: A microenvironmental model of carcinogenesis. Nat Rev Cancer 2008;8:56-61.

169 Hanahan D, Weinberg RA: The hallmarks of cancer. Cell 2000;100:57-70.

170 Padhani AR, Miles KA: Multiparametric imaging of tumor response to therapy. Radiology 2010;256:348364.

171 Rutman AM, Kuo MD: Radiogenomics: creating a link between molecular diagnostics and diagnostic imaging. Eur J Radiol 2009;70:232-241.

172 Zinn PO, Mahajan B, Sathyan P, Singh SK, Majumder S, Jolesz FA, Colen RR: Radiogenomic mapping of edema/cellular invasion MRI-phenotypes in glioblastoma multiforme. PLoS ONE 2011;6:e25451.

173 Segal E, Sirlin CB, Ooi C, Adler AS, Gollub J, Chen X, Chan BK, Matcuk GR, Barry CT, Chang HY, Kuo MD: Decoding global gene expression programs in liver cancer by noninvasive imaging. Nat Biotechnol 2007;25:675-680.

174 Kuo MD, Gollub J, Sirlin CB, Ooi C, Chen X: Radiogenomic analysis to identify imaging phenotypes associated with drug response gene expression programs in hepatocellular carcinoma. J Vasc Interv Radiol 2007;18:821-831.

175 Braren R, Altomonte J, Settles M, Neff F, Esposito I, Ebert O, Schwaiger M, Rummeny E, Steingoetter A: Validation of preclinical multiparametric imaging for prediction of necrosis in hepatocellular carcinoma after embolization. J Hepatol 2011;55:1034-1040.

176 Llovet JM, Bruix J: Molecular targeted therapies in hepatocellular carcinoma. Hepatology 2008;48:13121327.

177 Mínguez B, Tovar V, Chiang D, Villanueva A, Llovet JM: Pathogenesis of hepatocellular carcinoma and molecular therapies. Curr Opin Gastroenterol 2009;25:186-194.

178 Olsen SK, Brown RS, Siegel AB: Hepatocellular carcinoma: review of current treatment with a focus on targeted molecular therapies. Therap Adv Gastroenterol 2010;3:55-66.

179 Tremosini S, Reig M, de Lope CR, Forner A, Bruix J: Treatment of early hepatocellular carcinoma: Towards personalized therapy. Dig Liver Dis 2010;42(Suppl 3):S242-S248. 